University of Nebraska - Lincoln

DigitalCommons@University of Nebraska - Lincoln

1999

\title{
Twenty-year home-range dynamics of a white-tailed deer matriline
}

Michael E. Nelson

Northern Prairie Wildlife Research Center

L. D. Mech

Northern Prairie Wildlife Research Center

Follow this and additional works at: https://digitalcommons.unl.edu/usgsnpwrc

Part of the Animal Sciences Commons, Behavior and Ethology Commons, Biodiversity Commons, Environmental Policy Commons, Recreation, Parks and Tourism Administration Commons, and the Terrestrial and Aquatic Ecology Commons

Nelson, Michael E. and Mech, L. D., "Twenty-year home-range dynamics of a white-tailed deer matriline" (1999). USGS Northern Prairie Wildlife Research Center. 405.

https://digitalcommons.unl.edu/usgsnpwrc/405

This Article is brought to you for free and open access by the US Geological Survey at DigitalCommons@University of Nebraska - Lincoln. It has been accepted for inclusion in USGS Northern Prairie Wildlife Research Center by an authorized administrator of DigitalCommons@University of Nebraska - Lincoln. 


\title{
Twenty-year home-range dynamics of a white-tailed deer matriline
}

\author{
Michael E. Nelson and L. David Mech
}

\begin{abstract}
We examined the seasonal migration and home-range dynamics of a multigeneration white-tailed deer (Odocoileus virginianus) matriline comprising six females from four generations spanning a 20-year period in northeastern Minnesota. All, from the matriarch to her great-granddaughter, migrated to the same summer and winter ranges, the longest individual record being 14.5 years. Three maternal females concurrently occupied exclusive fawning sites within their ancestral matriarch's summer range, while two nonmaternal females explored new areas and ranged near their mothers. One great-granddaughter expanded her summer range $1 \mathrm{~km}$ beyond the matriarch's summer range while essentially vacating half of her ancestors' range and becoming nonmigratory the last 4 years of her life. These data indicate that individual movements of matriline members can potentially expand their ranges beyond the areas occupied by their ancestors through a slow process of small incremental changes. This suggests that the rapid extension of deer range in eastern North America resulted from natal dispersal by yearling deer rather than from the type of home-range expansion reported here.
\end{abstract}

Résumé : Nous avons étudié la migration saisonnière et la dynamique des déplacements dans les domaines au sein d'une lignée maternelle de plusieurs générations de Cerfs de Virginie (Odocoileus virginianus), lignée composée de six femelles de quatre générations recouvrant une période de 20 ans dans le nord-est du Minnesota. De l'aïeule à son arrière-petite-fille, toutes les femelles occupaient les mêmes domaines d'été et d'hiver, le record d'occupation atteignant 14,5 ans. Trois femelles mères occupaient en même temps des sites de mise-bas exclusifs à l'intérieur du domaine ancestral d'été, alors que deux femelles non mères ont exploré de nouvelles régions et occupaient des domaines voisins de ceux de leurs mères. Une arrière-petite-fille a étendu son domaine d'été de $1 \mathrm{~km}$ au-delà de celui de son aïeule, évacuant la moitié du domaine ancestral, et a cessé de migrer au cours des 4 dernières années de sa vie. Ces données indiquent que les déplacements des femelles d'une lignée maternelle peuvent éventuellement agrandir les domaines audelà des limites du domaine de leurs ancêtres, mais très lentement et par petites augmentations seulement. Il semble donc que l'expansion rapide de la répartition du Cerf de Virginie observée en Amérique du Nord résulte de la dispersion des jeunes de l'année à la naissance plutôt que du type d'expansion de domaine tel que décrit ici.

[Traduit par la Rédaction]

\section{Introduction}

Research and management of white-tailed deer (Odocoileus virginianus) have focused primarily on the relationship between habitat and physiological condition and their contribution to reproduction (Halls 1984). That living space and habitat availability could be constrained by such factors as social and genetic relationships to neighbors has been little studied (Miller 1974; Staines 1974).

However, female white-tailed deer live in multigeneration matriarchies (Townsend and Smith 1933; Palmer 1951; Severinghaus and Cheatum 1956; Hawkins and Klimstra 1970), which potentially leads to resource competition among relatives and nonrelatives alike. Nixon et al. (1991) found yearling daughters sharing home ranges with their mothers throughout life, and related females with $100 \%$ home-range overlap successfully raising fawns but never be- ing radiolocated together during the fawn-rearing period. Ozoga et al. (1982), studying an enclosed herd, also documented spatial exclusion among related females during fawning. Both studies confirmed what has long been regarded as typical behavior by maternal females, social and spatial seclusion in the presence of their newborn fawns (Townsend and Smith 1933; Palmer 1951; Hirth 1977). These studies examined spatial dynamics between mothers and various-aged daughters for up to 4 years.

A recent model of home-range dynamics of white-tailed deer proposes that populations expand spatially through slow incremental proliferation by progeny from matriarchal core ranges (Porter et al. 1991). The accuracy of such modeling depends upon a knowledge of long-term home-range dynamics of matriarchal units, including several generations. However, these dynamics and their effects on potential range extension remain largely unknown.

Received November 5, 1998. Accepted April 9, 1999.

M.E. Nelson ${ }^{1}$ and L.D. Mech. ${ }^{2}$ Biological Resources Division, U.S. Geological Survey, Northern Prairie Wildlife Research Center, 8711-37th Street SE, Jamestown, ND 58401-7317, U.S.A.

${ }^{1}$ Author to whom correspondence should be sent at the following address: Kawishiwi Field Laboratory, SR 1, Box 7200, Ely, MN 55731, U.S.A.

${ }^{2}$ Mailing address: North Central Forest Experiment Station, 1992 Folwell Avenue, St. Paul, MN 55108, U.S.A. 
Fig. 1. Genetic relationships, ages, and years of first capture and end of radio-tracking interval for a 20-year white-tailed deer matriline. Matriline members and their relationship to the matriarch are as follows: M112, matriarch; D106, daughter; G6381, granddaughter; G6996, granddaughter; GG6974, great-granddaughter; and GG7000, great-granddaughter. A dotted line represents life before capture and a solid line indicates the radio-tracking interval after capture.

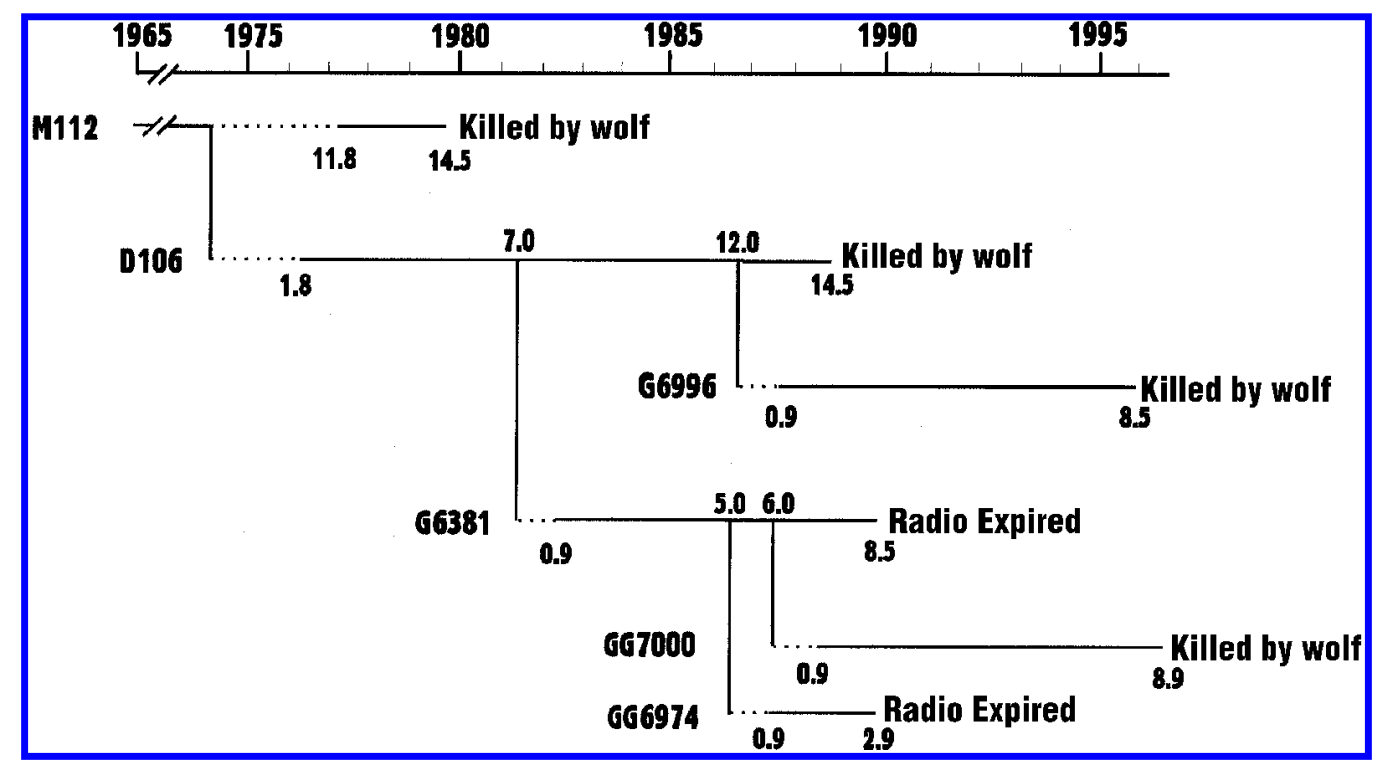

We report here the home-range dynamics of one multigeneration matriarchy comprising six females over a 20-year period and further evaluate these dynamics in the context of the white-tailed deer's range extension, based on our knowledge of deer dispersal (Hawkins and Klimstra 1970; Tierson et al. 1985; Dusek et al. 1989; Nelson 1993).

\section{Methods}

As part of long-term research on deer and wolf (Canis lupus) ecology, we studied six female deer during 1976-1996, all inhabiting a $3-\mathrm{km}^{2}$ area bordering Gabbro Lake in the Boundary Waters Canoe Area Wilderness (BWCAW) of the Superior National Forest in northeastern Minnesota $\left(48^{\circ} \mathrm{N}, 93^{\circ} \mathrm{W}\right)$ (Nelson and Mech 1981, 1986a, 1986b; Nelson 1993, 1995, 1998). The region is dominated by coniferous and deciduous forest described comprehensively by Heinselman (1996). All matriline members in this study migrated $10 \mathrm{~km}$ annually between their Gabbro Lake summer range and their Kawishiwi Campground wintering area $13 \mathrm{~km} \mathrm{SE}$ of Ely, Minnesota (Nelson and Mech 1987; Nelson 1998).

Summer deer densities approximated $0.3-0.7 / \mathrm{km}^{2}$ during 1976-1983 to 2.5/ $\mathrm{km}^{2}$ during 1984-1988 (Nelson and Mech 1986b; Nelson 1990), and density remained unknown but high through 1995. The females in this matriline were legally protected from hunting and only died from wolf predation.

We captured most deer with other matriline members by rocket net during winter, aged adults using cementum annuli of the fourth incisor (canine) (Gilbert 1966), radio-collared the deer, and located them from aircraft a minimum of 1 or 2 times per week except during June-September in 1980-1996, when BWCAW management policy only permitted higher altitude confirmation of deer presence on summer range. We located deer by canoe weekly during JuneAugust in 1988 and 1990. Tracking error was 2 and 4 ha for aerial tracking (Hoskinson 1976) and canoe tracking (M.E. Nelson, unpublished data), respectively. We additionally confirmed summer range presence from ground positions $1.5 \mathrm{~km}$ from the Gabbro Lake summer range. Distributions of locations and summer range presence were examined to evaluate spatial use by individual deer.

We presumed 7- to 10-month-old fawns to be the offspring of the adult females with which they were captured because of the close association between mothers and offspring up to 1 year of age (Hawkins and Klimstra 1970; Nelson and Mech 1981; Nelson 1993). We considered postmigration home ranges in June to be natal ranges of all fawns and permanent movement $>4 \mathrm{~km}$ from them to be natal dispersal (Nelson 1993).

For clarity and ease of remembering relationships between deer, we named individual deer with respect to the matriarch of the matriline. The letters D, G, and GG preceding individual numbers denote a daughter, granddaughter, and great-granddaughter of the matriarch, respectively.

The animals selected for this analysis were the only deer we have studied that provided the combination of longevity, known family relatedness, and recapture over time that allows analysis of long-term spatial dynamics of related individuals.

\section{Results}

\section{Capture and demography}

We captured and radio-tracked six female deer for this study from 1976 through 1996, of which five had motherfawn relationships (Fig. 1). In different years we captured adult female D106 with fawns G6381 and G6996. We later twice recaptured G6381 as an adult, first with fawn GG6974 and a year later with fawn GG7000. Based on their association after capture, shared migration, and the shared area of summer range locations (Figs. 2 and 3), we considered the sixth female (M112) to be the mother of D106, known mother and grandmother to the other females. The advanced age of M112 and our knowledge of female dispersal suggest that she was at least a 10-year occupant of the site used by the other females. If she was not the mother of D106, then M112 was at the very least, and most plausibly, a close relative.

\section{Home-range dynamics}

During April through November in 1976-1996, we located members of the matriline 482 times and confirmed their presence aerially on each of an additional 479 checks, 
Fig. 2. Locations of M112 during March-November 1977 when she was 12 years old ( $n=39$ locations) and D106 during April-June 1976 when she was 2 years old ( $n=31$ locations). The locations of M112 were in the same area in 1977 and 1978 . The study area lies at $47^{\circ} 52^{\prime} \mathrm{N}$ and $91^{\circ} 37^{\prime} \mathrm{W}$.

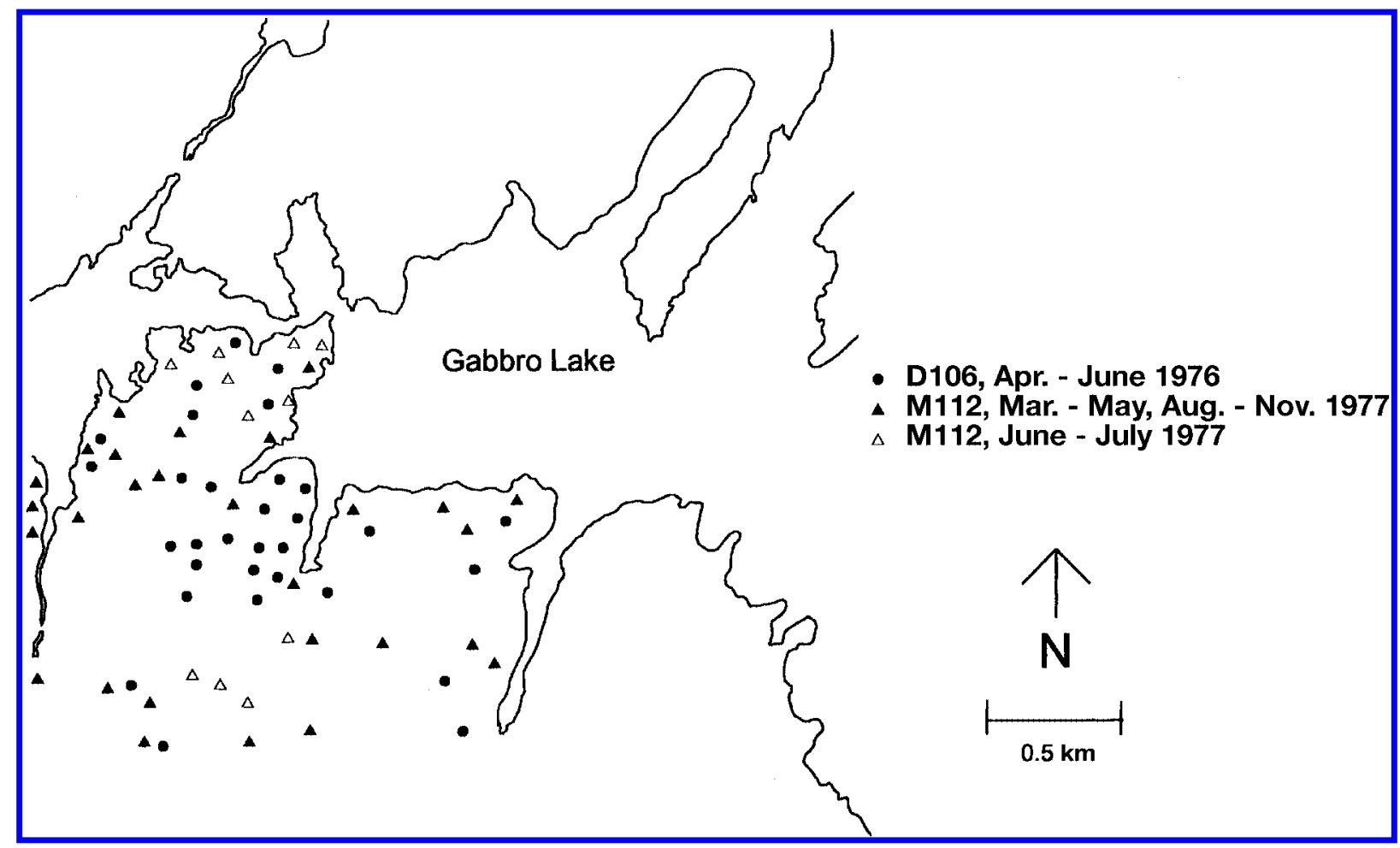

Fig. 3. Locations of M112 $(n=22)$ when she was 14 years old and D106 $(n=24)$ at 5 years old during April-November 1979.

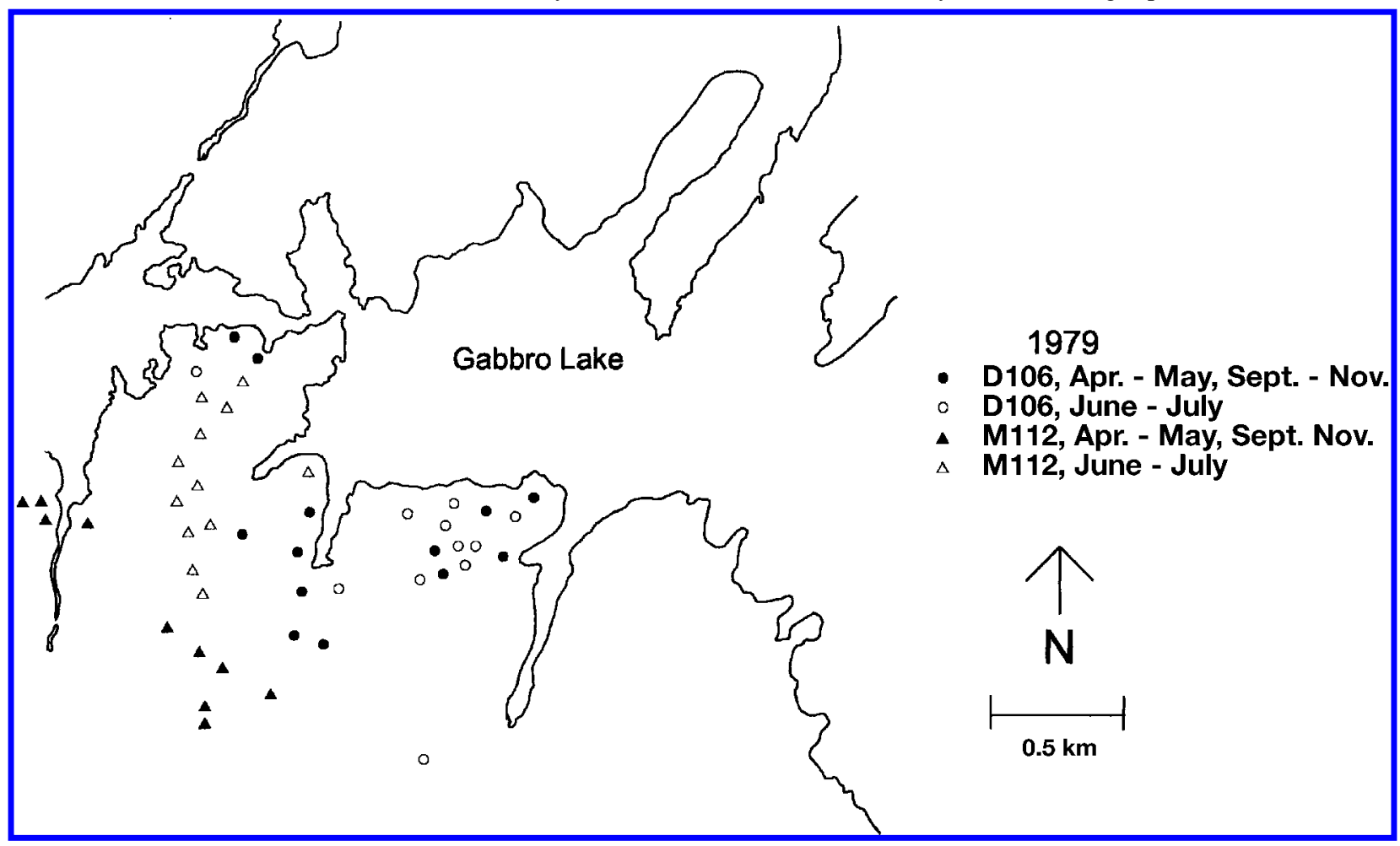

always within the same $3-\mathrm{km}^{2}$ area. We concurrently radiotracked five females during 1988, four during 1989, three in 1987, and two during 8 other years (Table 1). In 8 of the years we radio-tracked only one member.
M112

M112 annually migrated $10 \mathrm{~km}$ between the same winter and summer ranges from the time of her capture in 1977 to her death in 1979. Her 1977 and 1978 locations occurred 
Table 1. Location data for six deer from the Gabbro Lake matriline in March-April through November-December.

\begin{tabular}{|c|c|c|c|c|c|}
\hline \multirow[b]{3}{*}{ Deer No. } & \multirow[b]{3}{*}{ Age } & \multirow[b]{3}{*}{ Year } & \multicolumn{3}{|l|}{ Summer range } \\
\hline & & & \multirow[b]{2}{*}{$\begin{array}{l}\text { No. of aerial } \\
\text { locations }\end{array}$} & \multicolumn{2}{|c|}{$\begin{array}{l}\text { No. of times } \\
\text { confirmed present }\end{array}$} \\
\hline & & & & $\begin{array}{l}\text { Aerial } \\
\text { survey }\end{array}$ & $\begin{array}{l}\text { Ground } \\
\text { survey }\end{array}$ \\
\hline \multirow[t]{3}{*}{ M112 } & 12 & 1977 & 39 & & \\
\hline & 13 & 1978 & 48 & & \\
\hline & 14 & 1979 & 22 & 9 & 4 \\
\hline Total & & & 109 & 9 & 4 \\
\hline \multirow[t]{10}{*}{ D106 } & 2 & 1976 & 31 & & \\
\hline & 5 & 1979 & 24 & 8 & 6 \\
\hline & 6 & 1980 & 12 & 8 & \\
\hline & 7 & 1981 & 6 & 8 & \\
\hline & 8 & 1982 & 8 & 10 & 3 \\
\hline & 9 & 1983 & 18 & 11 & 2 \\
\hline & 10 & 1984 & 9 & 3 & \\
\hline & 11 & 1985 & 18 & 3 & \\
\hline & 13 & 1987 & 5 & 19 & 9 \\
\hline & 14 & 1988 & 23 & 4 & 8 \\
\hline Total & & & 154 & 74 & 28 \\
\hline \multirow[t]{8}{*}{ G6381 } & 1 & 1982 & 8 & 9 & 3 \\
\hline & 2 & 1983 & 14 & 11 & \\
\hline & 3 & 1984 & 9 & 3 & \\
\hline & 4 & 1985 & 10 & 4 & \\
\hline & 5 & 1986 & 2 & 8 & \\
\hline & 6 & 1987 & 3 & 18 & 24 \\
\hline & 7 & 1988 & 24 & 9 & 8 \\
\hline & 8 & 1989 & 5 & 19 & \\
\hline Total & & & 75 & 81 & 35 \\
\hline \multirow[t]{5}{*}{ G6996 } & 1 & 1987 & 3 & 15 & 29 \\
\hline & 2 & 1988 & 23 & 9 & 8 \\
\hline & 3 & 1989 & 5 & 21 & \\
\hline & 4 & 1990 & 19 & 14 & 9 \\
\hline & 5 & 1991 & 1 & 16 & 4 \\
\hline Total & & & 51 & 75 & 50 \\
\hline \multirow[t]{3}{*}{ GG6974 } & 1 & 1987 & 3 & 42 & \\
\hline & 2 & 1988 & 23 & 8 & 8 \\
\hline & 3 & 1989 & 4 & & \\
\hline Total & & & 30 & 50 & 8 \\
\hline \multirow[t]{9}{*}{ GG7000 } & 1 & 1988 & 21 & 11 & 8 \\
\hline & 2 & 1989 & 4 & 19 & 2 \\
\hline & 3 & 1990 & 19 & 13 & 6 \\
\hline & 4 & 1991 & 3 & 27 & 5 \\
\hline & 5 & 1992 & 4 & 31 & \\
\hline & 6 & 1993 & 4 & 23 & 16 \\
\hline & 7 & 1994 & 2 & 27 & 5 \\
\hline & 8 & 1995 & 2 & 33 & 17 \\
\hline & 9 & 1996 & 4 & 6 & 1 \\
\hline Total & & & 63 & 190 & 68 \\
\hline
\end{tabular}

Note: Data for deer G6381 in April-June 1986, deer G6996 in April-August 1991, deer GG6974 in April-May 1989, and deer GG7000 in January-November 1993 and 1995 and January-March 1996. within the same space as the 1976 locations of D106 (Fig. 2). We observed M112 twice before she and D106 migrated together to their shared summer range in 1979. They both raised fawns during that summer in exclusive areas $1 \mathrm{~km}$ apart but within the area they had both used previously (Fig. 3).

During June-July 1979, M112 intensively used the north section of her range, the same area she intensively used while rearing fawns in 1977 and 1978, and that D106 had frequented in 1976 as a 2-year-old.

\section{D106}

At the time of her death at 14.5 years old in 1988 , D106 continued to migrate between the same winter and summer ranges she used when we first radio-tracked her as a 2-yearold in 1976 (Table 1).

A 10 -year total of 154 locations of D106 on her summer range encompassed the space used by M112 during her tracking period (Table 1). The locations of the fawn-rearing sites used by D106 during the only 2 years when we determined them were centered $1 \mathrm{~km}$ apart. She raised her two fawns in the east part of her range during June-July 1979, while M112 raised her fawns in the north section (Fig. 3), the same area D106 had regularly occupied in 1976 (Fig. 2). After the death of M112, D106 used that area again, and as a primary area during fawning in 1988 (Fig. 4).

\section{G6381 and G6996}

G6381 migrated between her natal summer range and winter range during each year of her 6-year tracking tenure from 1982 to 1989 (Table 1). We located her 75 times and confirmed her presence on her summer range an additional 116 times, always within and fully using the area used by her mother and grandmother.

G6996 also migrated between her natal summer range and winter range during the 4 years (1987-1991) we followed her (Table 1). When 3.9 and 4.9 years old, she migrated to summer range with her niece GG7000. We observed them only once, migrating together with an unknown radio-collared female, most certainly G6381 or GG6974.

We located G 699651 times and confirmed her presence on summer range 125 times; we found her using only the west half of her mother's home range. She temporarily deviated $1 \mathrm{~km}$ northwest in 1988 when 2 years old (Fig. 5), but for the duration of her tracking tenure (1987-1991) she resumed using the west half of the area her deceased mother had used. Her locations in June-August 1990 indicated that she used the range her mother used in June-August 1988 (Fig. 6) and her grandmother used during fawn rearing in 1977-1979 (Figs. 2 and 3).

\section{GG6974 and GG7000}

Like the previous three generations, during the 3 years we radio-tracked GG6974 she migrated annually between the same summer and winter ranges as her mother, grandmother, and great-grandmother. During spring migrations when 1.9 and 2.9 years old, she accompanied her mother and younger sister GG7000. Her 30 summer range locations and 58 presence checks indicated that she occupied the same area as the other members of the matriline (Table 1). 
Fig. 4. Locations of D106, G6381, and GG6974 in 1988, when they were 14, 7, and 2 years old, respectively. (A) April-May ( $n=$ 10/deer). (B) June through August 15 ( $n=11 /$ deer).

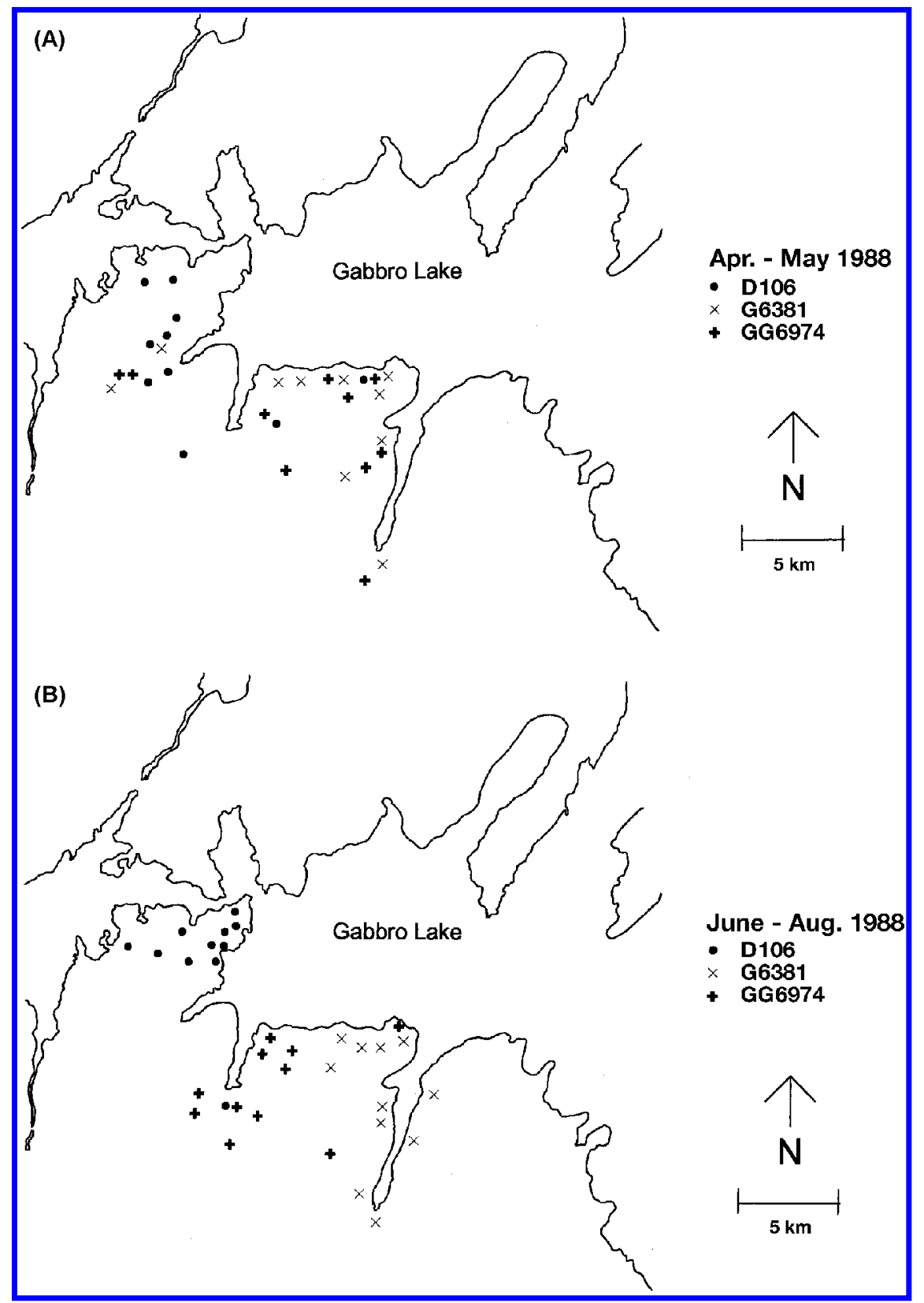

GG7000 also migrated annually to the summer and winter ranges used by the matriline. However, she differed markedly from her ancestors by becoming nonmigratory on her summer range when older. In late October 1992, when 5.5 years old, she migrated to her winter range for 3 days but returned to her summer range with her fawn. The following winter, when 6.9 years old, she again migrated to winter range but very late, 9 March, where we captured her with two male fawns. During the next 2 years, at 7.5 and 8.5 years old, she again remained on her summer range during winter and was killed there by wolves.

We located GG7000 63 times and confirmed her presence on summer range 258 times during 1988-1996 (Table 1). Unlike her mother, we found her only once in the west half of the matriline's range. As a yearling she remained near her mother but also explored new areas 1 and $3 \mathrm{~km}$ to the east and north, respectively, for periods less than 10-20 days. She repeated her northern foray as a 2-year-old but was never located there again during the subsequent 6 years. At 2 and 3 years of age she still only used the east half of her mother's area, but used her 1-km eastward expansion extensively as a core-activity area during fawning when 3 years old and as a primary area until her death at 8.9 years old.

\section{Summer range relationships}

Summer 1988, 9 years after the death of M112, provided our only opportunity to radio-track three generations of the matriline simultaneously, when D106, G6381, G6996, GG6974, and GG7000 concurrently used the same area (Figs. 4 and 5). Three of the females used exclusive sites, where we 
Fig. 5. Locations ( $n=10-20 /$ deer) of 2-year-old G6996 and 1-year-old GG7000 in April-August 1988. Two locations 2 km north of Gabbro Lake during July are not shown for GG7000.

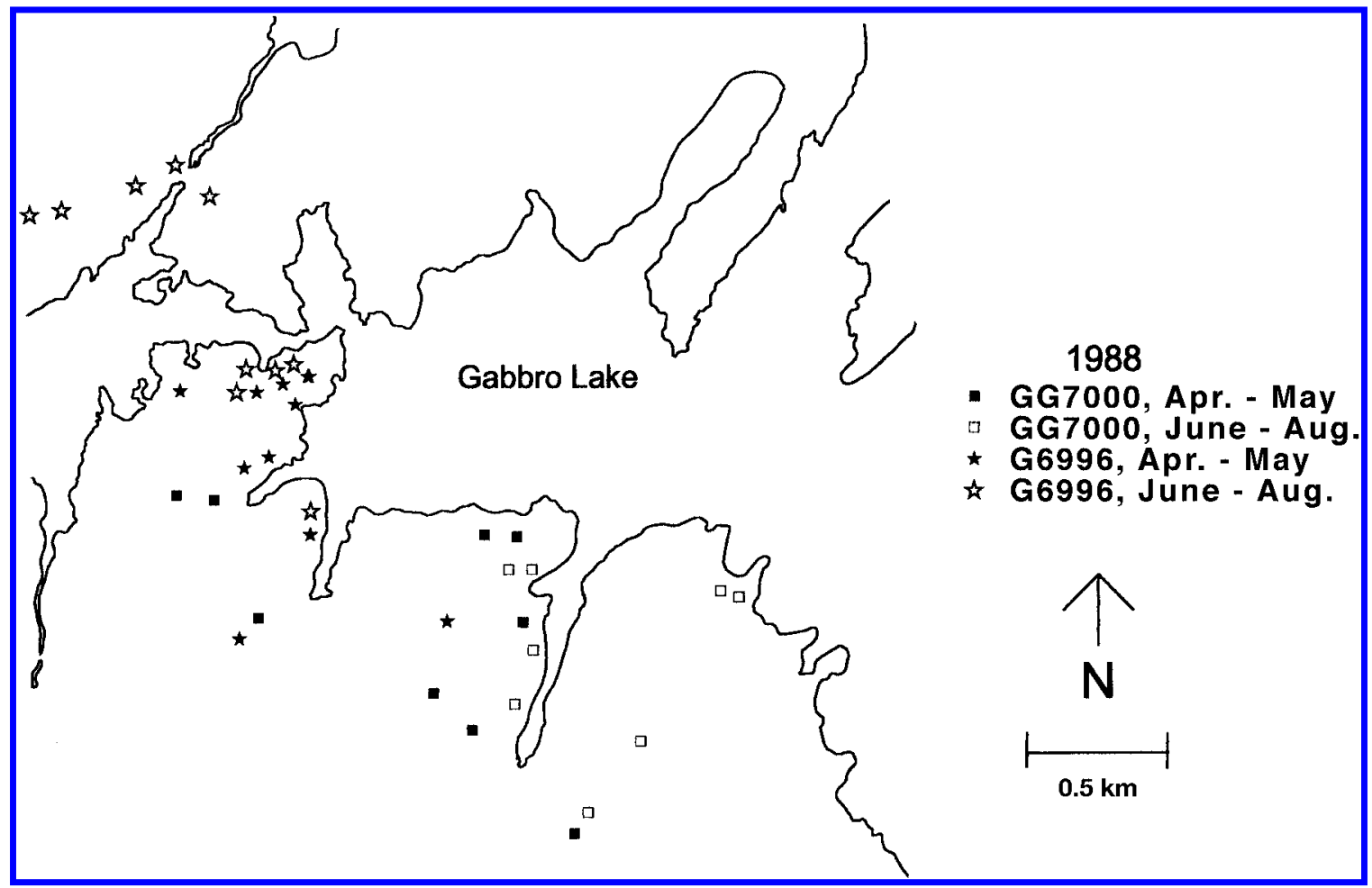

Fig. 6. Locations $(n=19 /$ deer) of 4-year-old G6996 and 3-year-old GG7000 in April-October 1990. One location 2 km north of Gabbro Lake in April is not shown for GG7000.

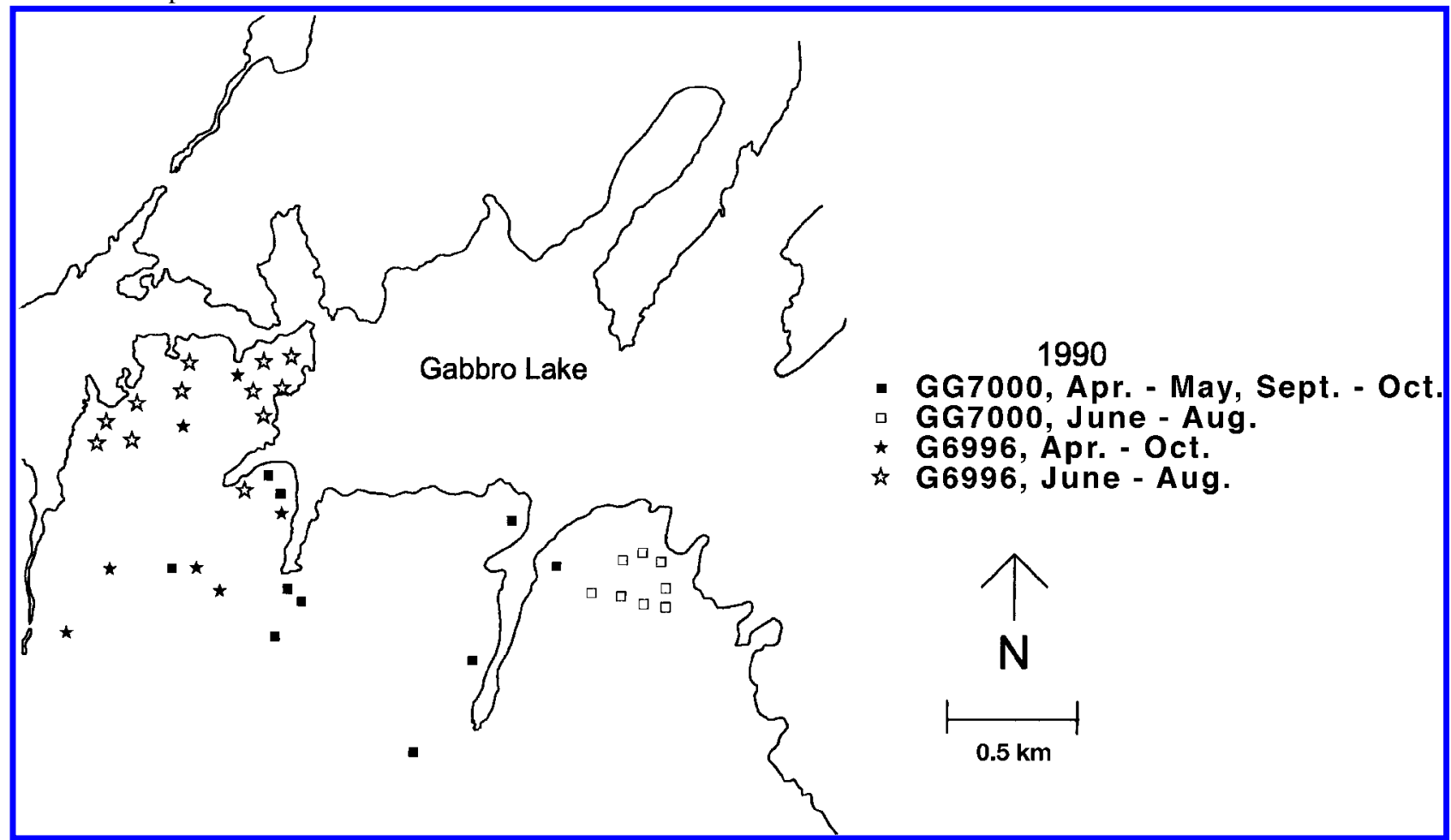

located them $90 \%$ of the time during June through midAugust. In contrast, we found two near their mother $40 \%$ of the time, but they also explored new areas $1-3 \mathrm{~km}$ beyond their previous locations. D106 used the 1977-1979 fawning site of her mother, $1 \mathrm{~km}$ from her own fawning site when 5 years old, and quite possibly the location of her own birth in 
1974. Also, G6381 used much of her mother's 1979 fawnrearing site, and GG6974 established an exclusive site between those of her mother and grandmother. All three females moved throughout the original home range of M112 in spring and fall during their tracking tenure, but never expanded beyond its original boundaries.

\section{Discussion}

Our finding that females from a single matriline occupied the same summer range during a 20-year period, some concurrently and others separately in time, is not unexpected. Hawkins and Klimstra (1970) demonstrated a high frequency of association between related females, and a low female dispersal rate, both of which we also observed (Nelson and Mech 1981; Nelson 1993). We later documented high philopatry by five other female fawns, one followed to 5 years old, and by nine other adult females followed for a minimum of 3-8 years (Nelson and Mech 1984, 1987). Tierson et al. (1985) reported that yearling and 2-year-old females established home ranges overlapping and adjacent to their mothers' ranges, as did Nixon et al. (1991) for older females as well. Recently, Aycrigg and Porter (1997) also reported a 15 -year record of philopatry by one female. These findings predict a high degree of relatedness and spatial stability among adjacent females. The spatial persistence of the matriline in our study and the evidence from other studies carried out in different environments suggest that matriarchal behavior and philopatry are deep-seated traits in the genome, the longterm products of evolution.

The related females we studied showed much spatial overlap in their locations, although they maintained exclusive sites during fawn rearing. The literature emphasizes aggression as the mechanism causing spacing, but observations of the tolerance of maternal females towards other deer in the absence of their fawns suggest that either aggression is limited to the vicinity of the fawn and (or) that deer mutually avoid each other rather than actively search for potential intruders (Dasmann and Taber 1956; Hirth 1977; Robinette et al. 1977; Nixon et al. 1991). Whatever the mechanism, after 4-6 weeks fawns begin to travel with mothers, and social tolerance by maternal females increases (Dasmann and Taber 1956; Hirth 1977; Robinette et al. 1977).

Aycrigg and Porter (1997) observed exclusive ranges only for 5-year-old females and considered them to be a result of social dominance. However, it is unclear how their finding is affected by the lower frequency of older females than of more abundant younger ones and the use of 50\% homerange polygons in their spatial analysis. Furthermore, evidence for a mechanism for exclusive range use other than during early fawn rearing is lacking.

Except for one great-granddaughter's small range expansion and new fawn-rearing area, our matriline's other females used sites within the matriarch's original range, and three of them used the same fawn-rearing sites as their mothers before them, but only after their mothers had died or also changed sites. Ozoga et al. (1982) documented successive annual use of the same fawning site by a matriarch, as well as shifting site use by her nearby daughter. Nixon et al. (1991) also observed a female's fawning site change between years but they attributed this to the presence of an aggressive female.

Obvious individual differences in site use existed between members of our matriline, although they used a common area. A granddaughter and great-granddaughter in our study appeared to abandon their use of different halves of the original matriline's range. For one female, this could have been partially or entirely the result of home-range expansion, but this does not explain why the result is the same for the other female. Conceivably, the presence and fawning territoriality of other maternal females also played a role in those dynamics.

The effects of deer density on matriarchal range dynamics should be manifested most directly through female dispersal. Theoretically, high density should create competition for space and resources that should precipitate higher female dispersal, thus disrupting matriline dynamics. However, the evidence does not support this notion. Two studies that examined dispersal at high densities (27-38 deer $/ \mathrm{km}^{2}$ ) found dispersal rates comparable to dispersal in our low-density (1-3 deer $/ \mathrm{km}^{2}$ ) population, and in both, matriarchies and (or) matrilineal ranges were observed (Hawkins and Klimstra 1970; Nixon et al. 1991). One of those studies reported a higher female dispersal rate, but a more precise dispersal rate measured in a subsample of known mother-fawn pairs was much lower and comparable to our dispersal rate (Nixon et al. 1991). In addition, the study showed no relationship between changing densities and dispersal rate, which was also observed in matriarchies of red deer (Cervus elaphus; Clutton-Brock et al. 1982).

Our results on spatial dynamics are from only one matriline, and two semicaptive matrilines produced the results of Ozoga et al. (1982) on spatial dynamics. Thus, it would be premature to generalize these findings. Many factors besides maternal territoriality may influence where females establish fawn-rearing sites (Nixon et al. 1991). Wolf predation and an extremely low deer density are relevant factors in our study, as are the barrier of a fence and a much higher deer density in Ozoga et al.'s (1982). In our study, a spatial vacancy due to predation and the absence of nearby conspecifics could have precluded dispersal or a small range expansion that was otherwise imminent if social pressure influences either process. However, our results do suggest that home-range expansion by free-ranging philopatric female white-tailed deer is an exceedingly slow process. Furthermore, the one female that expanded its range actually vacated a previously used portion of the original home range of the matriarch.

Based on the individual spatial dynamics they observed, Ozoga et al. (1982) concluded that deer range expansion depends upon the future production and survival of female progeny. Porter et al. (1991) similarly proposed that deer populations expand spatially through small incremental home-range additions by female progeny that overlap family ranges. They likened this process to the overlapping petals of a rose. The ages and home-range boundaries of females of unknown, but presumed, relatedness constituted the basis of their model. Our previous and present results confirm the validity of their model.

While the rose-petal metaphor is heuristically appealing, the complexities of home-range expansion which we ob- 
served indicate that such a model oversimplifies the reality of deer home-range dynamics, and does not adequately explain the rapid range extension of northern white-tailed deer in historic times (Halls 1984). However, the distances associated with natal dispersal are at least 1-2 orders of magnitude greater than that attributed to the rose-petal metaphor and do explain the rapid range extension. Our findings leave no doubt that such extension of deer range occurred primarily through short- and long-distance natal dispersal (Hawkins and Klimstra 1970; Nelson 1993), most of which was probably accomplished primarily by yearling males and to a small extent by less frequently dispersing yearling females (Downing and McGinnes 1976). During the rapid extension of the northern deer range in historic times, these males plus the occasional female positioned near the edge of deer range would have been the primary individuals colonizing new habitable areas, probably at a linear rate of $40-50 \mathrm{~km}$ per year (Nelson 1993).

\section{Acknowledgments}

This research was supported by the Patuxent Wildlife Research Center, U.S. Fish and Wildlife Service, U.S. Department of Agriculture North Central Forest Experiment Station, Mardag Foundation, and Special Projects Foundation of the Big Game Club. Reviews by Dr. Nancy Mathews and an anonymous reviewer improved the manuscript. We thank John Terwilliger for discovering and reporting the death of G6996. We further thank 60 individuals who assisted in capturing deer and extend our gratitude to the several pilots who skillfully flew the research aircraft, including current pilots Wayne Erickson and Dean Lee of the U.S. Forest Service.

\section{References}

Aycrigg, J.L., and Porter, W.F. 1997. Sociospatial dynamics of white-tailed deer in the central Adirondack mountains, New York. J. Mammal. 78: 468-482.

Clutton-Brock, T.H., Guinness, F.E., and Albon, S.D. 1982. Red deer, behavior and ecology of two sexes. University of Chicago Press, Chicago, Ill.

Dasmann, R.F., and Taber, R.D. 1956. Behavior of Columbian black-tailed deer with reference to population ecology. J. Mammal. 37: 143-163.

Downing, R.L., and McGinnes, B.S. 1976. Movement patterns of white-tailed deer in a Virginia enclosure. Proc. Annu. Conf. Southeast. Assoc. Game Fish Comm. 29: 454-459.

Downing, R.L., McGinnes, B.S., Petcher, R.P., and Sandt, J.L. 1969. Seasonal changes in movements of white-tailed deer. In White-tailed Deer in the Southern Forest Habitat: Proceedings of the Symposium, Nacogdoches, Texas, March 25-26. U.S. Department of Agriculture Forest Service, South, Forest Experiment Station, New Orleans. pp. 19-24.

Dusek, G.L., Mackie, R.J., Herriges, J.D., Jr., and Compton, B.B. 1989. Population ecology of white-tailed deer along the lower Yellowstone River. Wildl. Monogr. No. 104.

Gilbert, F.F. 1966. Aging white-tailed deer by annuli in the cementum of the first incisor. J. Wildl. Manage. 30: 200-202.

Halls, L.K. (Editor). 1984. White-tailed deer: ecology and management. Stackpole Books, Harrisburg, Pa.
Hawkins, R.E., and Klimstra, W.D. 1970. A preliminary study of the social organization of the white-tailed deer. J. Wildl. Manage. 34: 407-419.

Heinselman, M.L. 1996. The boundary waters wilderness ecosystem. University of Minnesota Press, Minneapolis.

Hirth, D.H. 1977. Social behavior of white-tailed deer in relation to habitat. Wildl. Monogr. No. 5.

Hoskinson, R.L. 1976. The effect of different pilots on aerial telemetry error. J. Wildl. Manage. 40: 137-139.

Miller, F.L. 1974. Four types of territoriality observed in a herd of black-tailed deer. In The behavior of ungulates and its relation to management. Vol. 2. Edited by V. Geist and F. Walter. IUCN New Ser., Publ. No. 24. International Union for the Conservation of Nature and Natural Resources, Morges, Switzerland. pp. 644-660.

Nelson, M.E. 1990. Gene flow, effective population size, genetic population structure in white-tailed deer in northeastern Minnesota. Ph.D. thesis, University of Minnesota, St. Paul.

Nelson, M.E. 1993. Natal dispersal and gene flow in white-tailed deer in northeastern Minnesota. J. Mammal. 74: 316-322.

Nelson, M.E. 1995. Winter range arrival and departure of whitetailed deer in northeastern Minnesota. Can. J. Zool. 73: 1069-1076.

Nelson, M.E. 1998. Development of migration behavior in northern white-tailed deer. Can. J. Zool. 76: 426-432.

Nelson, M.E., and Mech, L.D. 1981. Deer social organization and wolf predation in northeastern Minnesota. Wildl. Monogr. No. 77.

Nelson, M.E., and Mech, L.D. 1984. Home range formation and dispersal of deer in northeastern Minnesota. J. Mammal. 65: 567-575.

Nelson, M.E., and Mech, L.D. 1986a. Mortality of white-tailed deer in northeastern Minnesota. J. Wildl. Manage. 50: 691-698.

Nelson, M.E., and Mech, L.D. 1986b. Deer population in the central Superior National Forest, 1967-1985. U.S. For. Serv. Res. Pap. NC-271.

Nelson, M.E., and Mech, L.D. 1987. Demes within a northeastern Minnesota deer population. In Mammalian dispersal patterns. Edited by B.D. Chepko-Sade and Z. Halpin. University of Chicago Press, Chicago. pp. 27-40.

Nixon, C.M., Hansen, L.P., Brewer, P.A., and Chelsvig, J.E. 1991. Ecology of white-tailed deer in an intensively farmed region of Illinois. Wildl. Monogr. No. 118.

Ozoga, J.J., Verme, L.J., and Bienz, C.S. 1982. Parturition behavior and territoriality in white-tailed deer: impact on neonatal mortality. J. Wildl. Manage. 46: 1-11.

Palmer, R.S. 1951. The white-tailed deer of Tomhegan Camps, Maine, with added notes on fecundity. J. Mammal. 32: 267-280.

Porter, W.F., Mathews, N.E., Underwood, H.B., Sage, R.W., and Behrend, D.F. 1991. Social organization in deer: implications for localized management. Environ. Manage. 15: 809-814.

Robinette, W.L., Hancock, N.V., and Jones, D.A. 1977. The Oak Creek mule deer herd in Utah. Publ. No. 77-15, Utah Division of Wildlife Resources, Salt Lake City.

Severinghaus, C.W., and Cheatum, E.L. 1956. Life and times of the white-tailed deer. In The deer of North America. Edited by W.P. Taylor, The Stackpole Co., Harrisburg, Pa. pp. 57-186.

Staines, B.W. 1974. A review of factors affecting deer dispersion and their relevance to management. Mammal Rev. 4: 79-91.

Tierson, W.C., Mattfeld, G.F., Sage, R.W., and Behrend, D.F. 1985. Seasonal movements and home ranges of white-tailed deer in the Adirondacks. J. Wildl. Manage. 49: 760-769.

Townsend, M.T., and Smith, M.W. 1933. The white-tailed deer of the Adirondacks. Roosevelt Wildl. Bull. 6: 161-325. 